\title{
BIOLOGICALLY ACTIVE COMPOUNDS FROM THE RHIZOMES OF IRIS HUNGARICA
}

\author{
0.O.Mykhailenko, V.M.Kovalyov, S.V.Kovalyov, A.V.Krechun
}

National University of Pharmacy

53, Pushkinska Str., Kharkiv, 61002, Ukraine. E-mail: gnosy@nuph.edu.ua

Key words: isoflavonoids; irigenin; iristectorigenin B; iristectorin B; Iris hungarica; UV-, IR-, MS-, NOESY-, ${ }^{1} \mathrm{H} N M R$-spectra

Species of Iris genus (Iridaceae) have a long history of traditional medicinal use in different countries as alternative aperient, tonic, cathartic, diuretic, gall bladder diseases, liver complaints, dropsy, purification of blood, venereal infections, fever, bilious infections and for a variety of heart diseases. The rhizomes of Iris are the rich source of the secondary metabolites, in which flavonoids predominate. The clinical studies of substances from irises gave positive results in the treatment of cancer, bacterial and viral infections. Continuing the search of new biologically active compounds from the plants of Iridaceae family for the first time three isoflavones that are new for this species - irigenin, iristectorigenin B and its glucoside iristectorin B have been isolated from the ethanolic extract of the rhizomes of Iris hungarica Waldst. et Kit., which is widespread in Ukraine. The structure of the compounds is described as 5,7,3'-trihydroxy-6,4',5'-trimethoxyisoflavone, 5,7,4'-trihydroxy-6,3'-dimethoxyisoflavone and iristectorigenin B-7-O- $\beta-D$-glucoside, respectively. The compounds were obtained from the ethyl acetate fraction of the iris rhizomes by column chromatography on silica gel with sequential elution of the chloroform ethanol solvent with different concentrations. The structure of the compounds has been determined by chemical and spectral methods and in comparison with the literature data.

\section{БІОЛОГІЧНО АКТИВНI СПОЛУКИ КОРЕНЕВИЩ IRIS HUNGARICA}

О.О.Михайленко, В.М.Ковальов, С.В.Ковальов, А.В.Кречун

Ключові слова: ізофлавоноїди; іригенін; іристекторигенін В; іристекторин В; Iris hungarica; УФ-, $14-,{ }^{1} H$ ЯMP-, NOESY-спектроскопія; мас-спектрометрія

Рослини роду Iris (Iridaceae) мають давню історію застосування у традиційній медицині різних країн як альтернативний проносний, тонізуючий, відхаркувальний, сечогінний засіб, для лікування захворювань жовчного міхура, печінки, водянки, для очищення крові, венеричних інфекцій, лихоманки, жовчних інфрекцій і для лікування захворювань серця. Кореневища ірисів є багатим джерелом вторинних метаболітів, серед яких переважають фрлавоноїди. Клінічні дослідження речовин із ірисів дали позитивні результати при лікуванні раку, бактеріальних і вірусних інфекцій. Продовжуючи пошук нових біологічно активних сполук з рослин родини ірисові - Iridaceаe з етанольного екстракту кореневищ ірису угорського - Iris hungarica Waldst. et Kit., поширеного на території України, вперше виділено три нові для даного виду ізофрлавоноїди: іригенін, іристекторигенін В і його глюкозид іристекторин В. Структура речовин охарактеризована як 5,7,3'-тригідрокси-6, 4',5'-триметоксіізофрлавон, 5, 7, 4'-тригідрокси-6, 3'диметоксіізофрлавон та іристекторигенін B-7-O- $\beta-D-$-гюкопіранозид, відповідно. Речовини були отримані методом колонкової хроматограффії на силікагелі з етилацетатної фракції кореневищ ірису при послідовному елююванні розчинником хлороформ - етанол різної концентрації. Структура речовин встановлена хімічними і спектральними методами та у порівнянні з літературними даними.

\section{БИОЛОГИЧЕСКИ АКТИВНЫЕ СОЕДИНЕНИЯ КОРНЕВИЩ IRIS HUNGARICA}

\section{О.А.Михайленко, В.Н.Ковалев, С.В.Ковалев, А.В.Кречун}

Ключевые слова: изофрлавоноиды; иригенин; иристекторигенин В; иристекторин В; Iris hungarica; УФ-, ИК-, 'Н ЯMP-, NOESY-спектроскопия, масс-спектрометрия

Растения рода Iris (Iridaceae) имеют давнюю историю применения в традиционной медицине различных стран как альтернативное слабительное, тонизирующее, отхаркивающее, мочегонное средство, для лечения заболеваний желчного пузыря, печени, водянки, для очищения крови, лечения венерических инфекций, лихорадки, желчных инфекций и заболеваний сердца. Корневища ирисов являются богатым источником вторичных метаболитов, среди которых преобладают фрлавоноиды. Клинические исследования веществ из ирисов дали положительные результаты при лечении рака, бактериальных и вирусных инфрекций. Продолжая поиск новых биологически активных соединений из растений семейства ирисовые - Iridaceae из этанольного экстракта корневищ ириса венгерского - Iris hungarica Waldst. et Kit., который широко распространен на территории Украины, впервые выделены три новых для данного вида изофрлавоноида: иригенин, иристекторигенин В и его глюкозид иристекторин В. Структура веществ охарактеризована как 5,7,3'-тригидрокси-6,4',5'-триметоксиизофрлавон, 5, 7,4'-тригидрокси6,3'-диметоксиизофрлавон и иристекторигенин B-7-О- $\beta$-D-глюкопиранозид, соответственно. Вещества были получены методом колоночной хроматографрии на силикагеле из этилацетатной фрракции корневищ ириса при последовательном элюировании растворителем хлороформ - этанол различной концентрации. Структура веществ установлена химическими и спектральными методами и в сравнении с литературными данными. 
Plants of Iris genus (the family Iridaceae) are perennial herbaceous plants of $30-100 \mathrm{~cm}$ in height, with well-developed ensiform leaves and peduncles, which are at the top of many large flowers: white, purple, violet. Iris is the genus of 260-300 species, which are mainly distributed across the Northern Hemisphere [1-2].

Iris hungarica Waldst. et Kit. (syn. Iris aphylla L.) is widely distributed in most parts of the world, including the flora of Ukraine, Russia, Belarus [3-4], and is also cultivated as an ornamental plant [1]. The analysis of the chemical composition has not almost been carried out, but the component composition of essential oils ( $\alpha$-irone, squalene, $\beta$-damascenone, geranylacetone, eugenol, etc.) [5] and fatty acids (myristic, linoleic, palmitic and others) [6] in rhizomes has been determined; xanthone mangiferin has been identified [7].

Plants of Iris genus are the rich source of the secondary metabolites: flavonoids [8], isoflavonoides and their glycosides, xanthones, quinones, triterpenoids and stilbene glycosides [9-11]. The clinical studies of biologically active compounds of irises gave positive results in the treatment of cancer, bacterial and viral infections [12-13].

The aim of the work was to isolate and identify phenolic compounds from the rhizomes of I. hungarica. The EtOAc extract of the rhizomes of I. hungarica was subjected to repeated chromatography on columns of silica gel to obtain compounds $2,6,7$. Compounds are soluble in ethanol, benzene, chloroform and are poorly soluble in water, diethyl ether and petroleum ether (Scheme).

The mass spectrum of compound 2 showed the molecular ion peak at $\mathrm{m} / \mathrm{z} 360\left(\mathrm{M}^{+}\right)$in agreement with the molecular formula $\mathrm{C}_{18} \mathrm{H}_{16} \mathrm{O}_{8}$. The chromatographic analysis of 2 using the system of $n$-butanol - acetic acid - water (4:1:2) $\left(\mathrm{R}_{f} 0.87\right)$ produced a spot with a dark fluorescence that was darkened by ammonia vapour. This was characteristic of 5-hydroxyisoflavones [14]. The UV spectrum 2 showed $\lambda$ max absorptions at 269 and $337 \mathrm{~nm}(\mathrm{sh})$, suggesting the isoflavone skeleton. The IR spectrum showed intense absorptions $\left(\mathrm{cm}^{-1}\right)$ at: $3380(\mathrm{OH}), 2975,2945,2834$ $\left(\mathrm{OCH}_{3}\right), 1667(\mathrm{C}=0), 1622,1585,1507,1572(\mathrm{C}=\mathrm{C})$, $1372,1061,1008\left(\mathrm{OCH}_{3}\right)$ functions in the molecule.

The ${ }^{1} \mathrm{H}$ NMR-spectrum 2 of the proton resonance for isoflavone $\mathrm{C}-2$ was located at $\delta 8.35 \mathrm{ppm}$, which

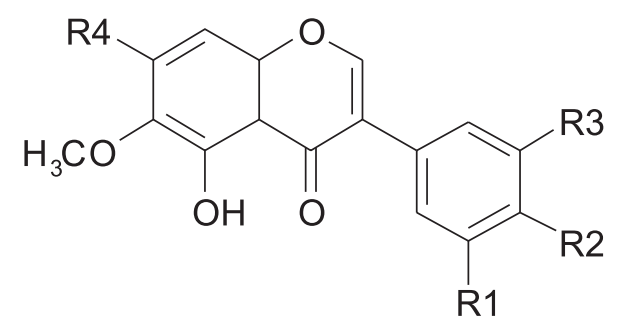

2: $\mathrm{R}_{1}=\mathrm{R}_{2}=\mathrm{OCH}_{3} ; \mathrm{R}_{3}=\mathrm{R}_{4}=\mathrm{OH} ; \mathbf{6}: \mathrm{R}_{1}=\mathrm{H} ; \mathrm{R}_{2}=\mathrm{R}_{4}=\mathrm{OH}$; $\mathrm{R}_{3}=\mathrm{OCH}_{3} ; 7: \mathrm{R}_{1}=\mathrm{H} ; \mathrm{R}_{2}=\mathrm{OH} ; \mathrm{R}_{3}=\mathrm{OCH}_{3} ; \mathrm{R}_{4}=\mathrm{O}$-Glu.

Scheme also confirmed the nature of the ring. The spectrum revealed the presence of three singlet signals of the hydroxyl groups at $\delta 13.0(1 \mathrm{H}, \mathrm{s}, 5-\mathrm{OH}), 10.75(1 \mathrm{H}, \mathrm{s}$, $7-\mathrm{OH}), 9.21\left(1 \mathrm{H}, \mathrm{s}, 3^{\prime}-\mathrm{OH}\right) \mathrm{ppm}$, and signals of three methoxy group at $\delta 3.3\left(3 \mathrm{H}, \mathrm{s}, 4^{\prime}-\mathrm{OCH}_{3}\right), 3.55(3 \mathrm{H}, \mathrm{s}$, 5 ' $\left.-\mathrm{OCH}_{3}\right), 3.8\left(3 \mathrm{H}, \mathrm{s}, 6-\mathrm{OCH}_{3}\right) \mathrm{ppm}$ and a one proton singlet at $\delta 6.42 \mathrm{ppm}$ for $\mathrm{H}-8$. The spectrum also showed a pair of doublets at $\delta 6.65 \mathrm{ppm}$ and $6.62 \mathrm{ppm}$ characteristic of the $p$-substituted benzene ring (each $2 \mathrm{H}, J=1.8 \mathrm{~Hz})$. It also exhibited a signal at $\delta 6.42(1 \mathrm{H}$, $\mathrm{s}, 8-\mathrm{H}) \mathrm{ppm}$, indicating that only one hydrogen atom was present on the A-ring of the isoflavone.

The data of the chemical analysis, the spectral characteristics of compound $\mathbf{2}$ are identical with the literature data on the structure of 5,7,3'-trihydroxy$6,4^{\prime}, 5^{\prime}$-trimethoxy isoflavone or irigenin. It was first isolated from the rhizomes of Iris hungarica [12].

The chromatographic analysis of compound $\mathbf{6}$ using the system of $15 \%$ acetic acid $\left(\mathrm{R}_{f} 0.49\right)$ produced a spot with a blue fluorescence. The mass spectrum of 6 showed the molecular ion peak at $\mathrm{m} / \mathrm{z} 330\left(\mathrm{M}^{+}\right)$in agreement with the molecular formula $\mathrm{C}_{17} \mathrm{H}_{14} \mathrm{O}_{7}$. UV absorption 6 maxima at 272 and $341 \mathrm{~nm}$ (sh) suggested the presence of the isoflavone moiety. In addition, the proton resonance for isoflavone $\mathrm{C}-2$ was located at $\delta 8.32(1 \mathrm{H}, \mathrm{s}) \mathrm{ppm}$, it also confirmed the nature of the ring. The IR-spectrum 6 showed intense absorptions at $3752 \mathrm{~cm}^{-1}(\mathrm{OH}), 2960,2836 \mathrm{~cm}^{-1}\left(\mathrm{OCH}_{3}\right)$, $1660 \mathrm{~cm}^{-1}(\mathrm{C}=0), 1622,1582,1522 \mathrm{~cm}^{-1}(\mathrm{C}=\mathrm{C}), 1372$, $1061,1008\left(\mathrm{OCH}_{3}\right)$.

The ${ }^{1} \mathrm{H}$ NMR-spectrum 6 exhibited signals at $\delta 8.35$ $(1 \mathrm{H}, \mathrm{s}), 7.12(1 \mathrm{H}, \mathrm{d}, \mathrm{J}=1.8 \mathrm{~Hz}), 6.60(1 \mathrm{H}, \mathrm{d}, J=2.4 \mathrm{~Hz})$, and $6.67(1 \mathrm{H}, \mathrm{dd}, J=2.4,1.8 \mathrm{~Hz}) \mathrm{ppm}$ attributable to $\mathrm{H}-2$ of the isoflavone and formed the spin-spin interaction ( $\mathrm{H}-5^{\prime}, \mathrm{H}-\mathrm{2}^{\prime}$ and $\left.\mathrm{H}-\mathrm{6}^{\prime}\right)$. It also exhibited a signal at $\delta 6.40(1 \mathrm{H}, \mathrm{s}, 8-\mathrm{H}) \mathrm{ppm}$, indicating that only one hydrogen atom was present on the A-ring of the isoflavone, and two signals each for two methoxy groups at $\delta 3.73\left(3 \mathrm{H}, \mathrm{s}, 3^{\prime}-\mathrm{OCH}_{3}\right)$ and $\delta 3.75\left(3 \mathrm{H}, \mathrm{s}, 6-\mathrm{OCH}_{3}\right)$ $\mathrm{ppm}$. The spectrum indicated the presence of three singlet signals of the hydroxyl groups at $\delta 13.05(1 \mathrm{H}$, s, 5-OH), $10.08(1 \mathrm{H}, \mathrm{s}, 7-\mathrm{OH}), 9.20\left(1 \mathrm{H}, \mathrm{s}, 4^{\prime}-\mathrm{OH}\right) \mathrm{ppm}$.

With NOESY spectrum $\mathbf{6}$ arrangements of the substituents at C-3' and C-4' were refined. The analysis showed the presence of two cross-peaks demonstrating the nuclear resonance, and they were spatially close (Nuclear Overhauser effect observed at a distance of 0.03-0.4 $\mathrm{nm}$ between atoms). The interaction of proton $\mathrm{H}-2$ with protons $\mathrm{H}-2$ ' and $\mathrm{H}-6$ ' was observed (Fig.). Proton $\mathrm{H}-2$ ' gave a cross-peak with the protons of the methoxy group, thus, it was located in position 3'.

The MS-, 1H NMR-, NOESY-, IR- and UV-spectra of 6 indicate that compound 6 is 5,7,4'-trihydroxy6,3'-dimethoxyisoflavone or iristectorigenin B first isolated from the rhizomes of I. hungarica [12].

The molecular formula of compound $7 \mathrm{C}_{23} \mathrm{H}_{24} \mathrm{O}_{12}$ was determined by the molecular ion peak at $\mathrm{m} / \mathrm{z}$ 


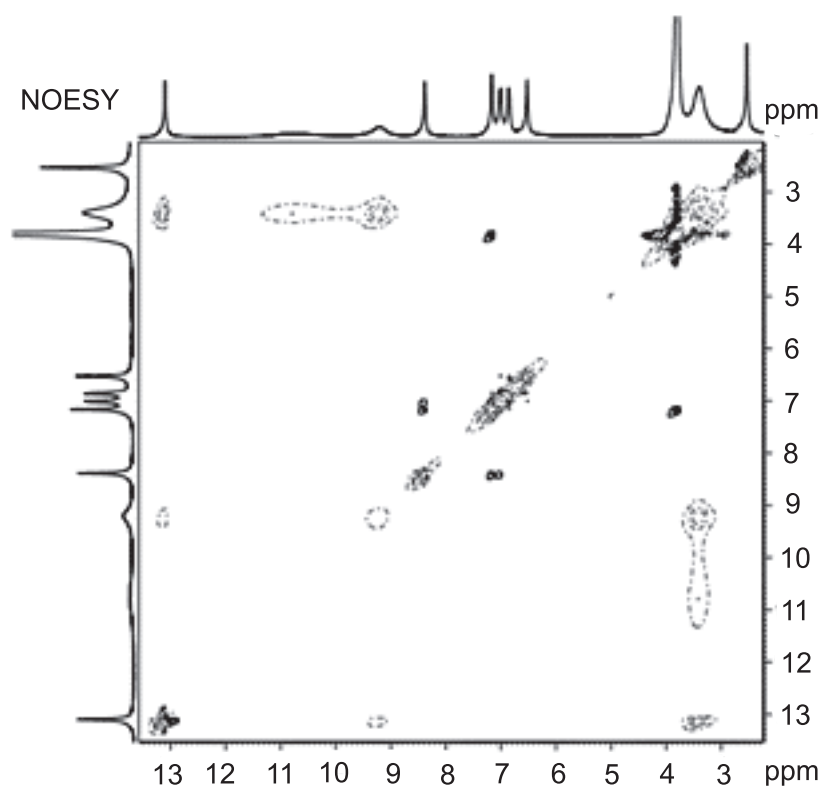

Fig. The NOESY spectrum for compound 6 .

$330\left(-C_{6} H_{11} O_{5}\right)\left(\mathrm{M}^{+}\right)$. It gave a positive reaction on the phenolic hydroxyl groups - a blackish-green colour with alcoholic $1 \% \mathrm{FeCl}_{3}$ and a violet-brown colour with aq. $1 \% \mathrm{FeCl}_{3}$ solutions.

The UV-spectrum of $\mathbf{7}$ showed the $\lambda$ max absorptions at 272 and $340 \mathrm{~nm}(\mathrm{sh})$, suggesting the isoflavone skeleton. In addition, the proton resonance for isoflavone $\mathrm{C}-2$ was located at $\delta 8.32(1 \mathrm{H}, \mathrm{s}) \mathrm{ppm}$, it also confirmed the nature of the ring. The IR-spectrum 7 showed intense absorptions at: $3423 \mathrm{~cm}^{-1}(\mathrm{OH})$, 2959, $2844 \mathrm{~cm}^{-1}\left(\mathrm{OCH}_{3}\right), 1660 \mathrm{~cm}^{-1}(\mathrm{C}=0), 1623,1583$, $1523 \mathrm{~cm}^{-1}(\mathrm{C}=\mathrm{C})$ functions in the molecule. There were three absorption bands $\mathrm{C}$-H carbohydrate residues at $1100-1010 \mathrm{~cm}^{-1}$ characterizing a pyranose form and the band at $890 \mathrm{~cm}^{-1}-\beta$-glycosidic linkage.

Acid hydrolysis of 7 with $10 \% \mathrm{H}_{2} \mathrm{SO}_{4}$ gave aglycone (iristectorigenin $\mathrm{B}$ ) and $D$-glucose and which were identified by co-PC and co-TLC.

The ${ }^{1} \mathrm{H}$ NMR-spectrum 7 indicated the isoflavonoid nucleus by the appearance of the $\mathrm{H}-2$ signal at $\delta 8.32(1 \mathrm{H}, \mathrm{s}) \mathrm{ppm}$. It had the aromatic nuclei spin system being the same as that of compound 6 . It also displayed signals at $\delta 7.15,6.90$ and $6.70 \mathrm{ppm}$ to form the spin-spin interaction $\left(\mathrm{H}-5^{\prime}, \mathrm{H}-\mathrm{2}^{\prime}\right.$ and $\left.\mathrm{H}-\mathrm{6}^{\prime}\right)$. The spectrum also showed signals for two methoxy groups at $\delta 3.75\left(3 \mathrm{H}, \mathrm{s}, 3^{\prime}-\mathrm{OCH}_{3}\right)$ and $\delta 3.70\left(3 \mathrm{H}, \mathrm{s}, 6-\mathrm{OCH}_{3}\right)$ ppm and one characteristic proton signal for $\mathrm{H}-8$ at $\delta 6.47(1 \mathrm{H}, \mathrm{s}) \mathrm{ppm}$. It also indicated the presence of two singlet signals of the hydroxyl groups at $\delta 13.10$ $(1 \mathrm{H}, \mathrm{s}, 5-\mathrm{OH}), 9.15\left(1 \mathrm{H}, \mathrm{s}, 4^{\prime}-\mathrm{OH}\right) \mathrm{ppm}$. The ${ }^{1} \mathrm{H}$ NMRspectrum unlike to the spectra of aglycone as iristectorigenin B further noted the presence of groups of signals corresponding to the presence of six protons confirming the glycoside monoside nature.

Based on these data we have concluded that $\mathbf{7}$ is iristectorigenin B-7-O- $\beta$ - $D$-glucoside or iristectorin $\mathrm{B}$ $\left(5,7,3^{\prime}\right.$-hydroxy-6,3'-dimethoxyisoflavone- $0-\beta-D$ - glucoside) isolated from the rhizomes of $I$. hungarica for the first time [12].

Irigenin, Iristectorigenin B and Iristectorin B were previously isolated from the rhizomes of I. dichitoma (2010), I. tectorum (1972), I. kumaonensis (1984), I. florentina L. (1973), I. milesii (1984) [12].

\section{Experimental Part}

\section{Devices and materials}

${ }^{1} \mathrm{H}$ NMR-spectra $(200 \mathrm{MHz}$ ) were recorded on a VarianMercury-VX-200 instrument (USA) in DMSO- $d_{6}$ with TMS as an internal standard. Low-resolution mass spectra were measured on a GC-MS Varian 1200L (ionizing voltage $-70 \mathrm{eV}$ ) instrument (USA). UV spectra $(\lambda, \mathrm{nm})$ were recorded on a Carl Zeiss Specord M-80 (Germany); Evolution 60S (USA); Spekol 1500 (Analytik Jena AG,Germany) spectrometers in EtOH. IRspectra ( $\mathrm{KBr}$ pellets) on a Tensor 27 UR-20 spectrometer (Germany). Column chromatography (CC) was carried out on silica gel, 100-200 (75-150 mesh) (USA). TLC used plates: silica gel $60 \mathrm{~F}_{254}$ TLC plates (Merck), Silufol UV $_{254}$ and paper "Filtrak" (FN-1;4). Spots were detected in UV light (365 $\mathrm{nm}$ and $254 \mathrm{~nm}$ ) after visualization by ammonia vapour. The melting point was determined on a Kofler bench (Franz Kustner Nacht KG, Dresden, Germany). The compound analyzed was dried in vacuo $\left(10^{-2} \mathrm{~mm} \mathrm{Hg}\right)$ over $P_{2} O_{5}$ at $110-115^{\circ} \mathrm{C}$ for 5 hours.

\section{Biological Material}

The rhizomes of $I$. hungarica were collected from M.M.Gryshko National Botanical Garden of the National Academy of Sciences of Ukraine, Kyiv in May of 2015 and were air-dried. Voucher specimens have been deposited in the Herbarium of the Pharmacognosy Department and Botany Department of the National University of Pharmacy, Kharkiv, Ukraine. The plant was identified by the Head of the Department of the Ornamental plants, Senior Researcher of M.M.Gryshko National Botanical Garden at the NAS of Ukraine (Kyiv), Cand. Biol. Sci. Yu.V.Buydin.

\section{Extraction and Isolation of Compounds}

Air-dried rhizomes $(2.5-3 \mathrm{~mm})$ of I. hungarica $(1.0 \mathrm{~kg})$ were extracted with EtOH $(70 \%, 5 \mathrm{~L})$ in a percolator for $24 \mathrm{~h}$. The extraction was repeated thrice under the same conditions. The aqueous EtOH extracts were combined, filtered, evaporated in a rotary evaporator to $0.5 \mathrm{~L}$ of the aqueous residue, and left for 1 day. The supernatant liquid was separated. The resulting extract was treated successively with $\mathrm{CHCl}_{3}, \mathrm{EtOAc}$ and $n-\mathrm{BuOH}$. The resulting extracts were evaporated in vacuo. The qualitative composition of $\mathrm{CHCl}_{3}, \mathrm{EtOAc}$ and $\mathrm{BuOH}$ fractions was controlled by PC and TLC in the solvent system of n-butanol - acetic acid - water (4:1:2).

The EtOAc extract was evaporated by heating under vacuum to complete stripping of the solvent, subjected to $\mathrm{CC}(120 \times 5 \mathrm{~cm})$ on silica gel and eluted with 
the gradient: $\mathrm{CHCl}_{3}$ and ethanol-mixtures $(9: 1 ; 8: 2$; $5: 4 ; 1: 5 ; 1: 1)$, and ethanol to obtain 110 fractions by $50 \mathrm{ml}$. Compound $2(600 \mathrm{mg})$ was detected in fractions of chloroform-ethanol $(9: 1)$, the compound 6 (80 $\mathrm{mg}$ ) and 7 (55 mg) - in chloroform-ethanol (8:2).

Chromatographic analysis of 2 using $n$-butanol acetic acid - water (4:1:2) produced a spot with a darkblue fluorescence, compounds 6 and 7 gave a dark fluorescence that was darkened by ammonia vapour.

\section{Spectral Data}

Irigenin (2) - 5,7,3'-trihydroxy-6,4',5'-trimethoxyisoflavone $-\mathrm{C}_{18} \mathrm{H}_{16} \mathrm{O}_{8}$, a yellow powder. M. p. $182-183^{\circ} \mathrm{C} . \mathrm{M} 360,32 \mathrm{~g} / \mathrm{Mol} . \mathrm{MS}, \mathrm{m} / \mathrm{z} 360\left(\mathrm{M}^{+}\right) . \mathrm{R}_{f} 0.87$, dark, system: $n$-butanol - acetic acid - water (4:1:2 by volume), TLC; UV $\lambda \max (\mathrm{EtOH}) \mathrm{nm}: 269,337$. IR (KBr), $v, \mathrm{~cm}^{-1}: 3380(\mathrm{OH}), 2975,2945,2834$ (OCH3), 1667 ( $\mathrm{C}=0$ ) , 1622, 1585, 1507, 1572 ( $\mathrm{C}=\mathrm{C}$ ), 1372, 1061, $1008\left(\mathrm{OCH}_{3}\right) .{ }^{1} \mathrm{H}$ NMR $\left(200 \mathrm{MHz}, \mathrm{DMSO}-d_{6}\right) \delta$, ppm: $13.0(1 \mathrm{H}, \mathrm{s}, 5-\mathrm{OH}), 10.75(1 \mathrm{H}, \mathrm{s}, 7-\mathrm{OH}), 9.21(1 \mathrm{H}, \mathrm{s}$, $\left.3^{\prime}-\mathrm{OH}\right), 8.35(1 \mathrm{H}, \mathrm{s}, \mathrm{H}-2), 6.65\left(2 \mathrm{H}, \mathrm{d}, J=1.8 \mathrm{~Hz}, \mathrm{H}-2^{\prime}\right)$, $6.62\left(2 \mathrm{H}, \mathrm{d}, J=1.8 \mathrm{~Hz}, \mathrm{H}-6^{\prime}\right), 6.42(1 \mathrm{H}, \mathrm{s}, \mathrm{H}-8), 3.3(3 \mathrm{H}$, $\left.\mathrm{s}, 4^{\prime}-\mathrm{OCH}_{3}\right), 3.55\left(3 \mathrm{H}, \mathrm{s}, 5^{\prime}-\mathrm{OCH}_{3}\right), 3.8\left(3 \mathrm{H}, \mathrm{s}, 6-\mathrm{OCH}_{3}\right)$.

Iristectorigenin $\mathrm{B}(6)$ - 5,7,4' - trihydroxy -6,3'- dimethoxyisoflavone $-\mathrm{C}_{17} \mathrm{H}_{14} \mathrm{O}_{7}$, a yellow powder. M. p. $151-153^{\circ} \mathrm{C} . \mathrm{M} 330,29 \mathrm{~g} / \mathrm{Mol}$. MS, m/z $330\left(\mathrm{M}^{+}\right) . \mathrm{R}_{f} 0.49$, dark, system 15\% HAc; TLC; UV $\lambda \max (\mathrm{EtOH}) \mathrm{nm}$ : 272, 341. IR (KBr), v, cm ${ }^{-1}: 3752(\mathrm{OH}), 2960,2836\left(\mathrm{OCH}_{3}\right)$, 1660 (C=0), 1622, 1582, 1522 (C=C), 1372, 1061, 1008
$\left(\mathrm{OCH}_{3}\right) .{ }^{1} \mathrm{H}$ NMR $\left(200 \mathrm{MHz}, \mathrm{DMSO}-d_{6}\right) \delta$, ppm: 13.05 (1H, s, 5-OH), $10.08(1 \mathrm{H}, \mathrm{s}, 7-\mathrm{OH}), 9.20\left(1 \mathrm{H}, \mathrm{s}, 4^{\prime}-\mathrm{OH}\right)$ $8.35(1 \mathrm{H}, \mathrm{s}, \mathrm{H}-2), 7.12\left(1 \mathrm{H}, \mathrm{d}, J=1.8 \mathrm{Mz}, \mathrm{H}-2^{\prime}\right), 6.60(1 \mathrm{H}$, $\left.\mathrm{d}, J=8.2 \mathrm{~Hz}, \mathrm{H}-5^{\prime}\right), 6.67\left(1 \mathrm{H}, \mathrm{dd}, \mathrm{J}=2.4 ; 1.8 \mathrm{~Hz}, \mathrm{H}-6^{\prime}\right), 6.40$ $(1 \mathrm{H}, \mathrm{s}, \mathrm{H}-8), 3.73\left(3 \mathrm{H}, \mathrm{s}, 3^{\prime}-\mathrm{OCH}_{3}\right), 3.75\left(3 \mathrm{H}, \mathrm{s}, 6-\mathrm{OCH}_{3}\right)$. Iristectorin $\mathrm{B}(7)$ - iristectorigenin B-7-0- $\beta$ - $D$-glucoside $-C_{23} H_{24} O_{12}$, a yellow powder. M. p. $-153-155^{\circ} \mathrm{C}$. M 492,44 g/Mol. MS, m/z $330\left(-C_{6} H_{11} O_{5}\right)\left(\mathrm{M}^{+}\right)$. UV $\lambda \max$ (EtOH) nm: 272, 340. IR (KBr), v, $\mathrm{cm}^{-1}: 3423(\mathrm{OH})$ 2959, $2844\left(\mathrm{OCH}_{3}\right), 1660(\mathrm{C}=0), 1623,1583,1523$ $(\mathrm{C}=\mathrm{C}), 1100-1010(\mathrm{C}-\mathrm{H}), 890$ ( $\beta$-glycosidic linkage). ${ }^{1} \mathrm{H}$ NMR $\left(200 \mathrm{MHz}, \mathrm{DMSO}-d_{6}\right) \delta$, ppm: $13.10(1 \mathrm{H}, \mathrm{s}$, 5-OH), $9.15\left(1 \mathrm{H}, \mathrm{s}, 4^{\prime}-\mathrm{OH}\right), 8.32(1 \mathrm{H}, \mathrm{s}, \mathrm{H}-2), 7.15$ $\left(1 \mathrm{H}, \mathrm{d}, J=1.8 \mathrm{~Hz}, \mathrm{H}-2^{\prime}\right), 6.90\left(1 \mathrm{H}, \mathrm{d}, J=8.2 \mathrm{~Hz}, \mathrm{H}-5^{\prime}\right)$, $6.70\left(1 \mathrm{H}, \mathrm{dd}, J=2.4 ; 1.8 \mathrm{~Hz}, \mathrm{H}-6^{\prime}\right), 6.47(1 \mathrm{H}, \mathrm{s}, \mathrm{H}-8)$, $3.75\left(3 \mathrm{H}, \mathrm{s}, 3^{\prime}-\mathrm{OCH}_{3}\right), 3.70\left(3 \mathrm{H}, \mathrm{s}, 6-\mathrm{OCH}_{3}\right), 5.1(1 \mathrm{H}, \mathrm{d}$, $\left.J=7,2 \mathrm{~Hz}, \mathrm{H}-1^{\prime \prime}\right), 4.60\left(1 \mathrm{H}, \mathrm{t}, J=9,0 \mathrm{~Hz}, \mathrm{H}-3^{\prime \prime}\right), 4.1(1 \mathrm{H}$, $\left.\mathrm{dd}, J=9.0,7.2 \mathrm{~Hz}, \mathrm{H}-5^{\prime \prime}\right), 3.47\left(1 \mathrm{H}, \mathrm{t}, J=9.0 \mathrm{~Hz}, \mathrm{H}-4^{\prime \prime}\right)$, $3.95\left(1 \mathrm{H}, \mathrm{d}, J=9.0 \mathrm{~Hz}, \mathrm{H}-6^{\prime \prime}\right), 3.70(1 \mathrm{H}, \mathrm{dd}, J=9.0$, $\left.7.2 \mathrm{~Hz}, \mathrm{H}-2^{\prime \prime}\right)$.

\section{Conclusions}

Isoflavonoids - irigenin, iristectorigenin B and its glucoside iristectorin $B$ have been isolated from the ethyl acetate extract of the rhizomes of Iris hungarica Waldst. et Kit. by column chromatography for the first time. The structure of compounds has been determined by chemical and spectral methods.

\section{References}

1. Goldblatt P., Manning J. C. The Iris family: natural history and classification. Portland, Timber Press, 2008,336 .

2. Rodionenko G. I. The genus Iris L.: (questions of morphology, biology evolution and systematics). British Iris Society, 1987,222 p.

3. Mosyakin S. L., Fedoronchuk M. M. Vascular plants of Ukraine: a nomenclatural checklist. Kiev, 1999, pp.31-33.

4. Czerepanov S. K. Vascular plants of Russia and adjacent states (the former USSR), Cambridge, 2007, pp.280-282.

5. Kovalev V. N., Mikhailenko O. A., Vinogradov B. A. Chemistry of Natural Compounds, 2014, Vol. 50, pp.161-162. http://rd.springer.com/article/10.1007/ s10600-014-0900-5

6. Kovalyov V. N., Mykchailenko O. A., Krechyn A. V. Rastitelnyi resyrsu, 2015, Vol. 3, pp.406-415.

7. Krechun A. V., Kovalev V. N., Mykhailenko O. O. Abstracts of Papers. Topical issues of new drugs development: abstracts of international scientific and practical conference of young scientists and student, Kharkiv, 2015, p.80.

8. Williams Ch. A., Harborne J. B., Colasante M. Biochemical systematics and ecology, 1997, Vol. 25 (4), pp.309-325.

9. Kassak P. Journal acta universitatis agriculturae et silviculturae mendelianae brunensis. 2012, Vol. LX(8), pp.269-280. http://acta.mendelu.cz/ media/pdf/actaun_2012060080269.pdf

10. Kukula-Koch W., Sieniawska E., Widelski J., Urjin O., Głowniak P., Skalicka-Woz'niak K. Phytochemistry reviews, 2013, Vol. 12(4), pp.1-32. DOI: 10.1007/s11101-013-9333-1

11. Wang H., Yanmei C., Changqi Z. Mini Reviews in Medicinal Chemistry, 2010, Vol. 10, pp.643-661. D0I: 10.2174/138955710791384027

12. Zhou J., Xie G., Yan X. Encyclopedia of traditional Chinese medicines, Vol. 3, Berlin, Heidelberg; New York, Springer, 2011,669 p.

13. Zatylnikova O. A., Osolodchenko T. P., Kovalev V. N. Scientific J. Annals of Mechnikov's Institute, 2010, Vol. 4, pp.43-47.

14. Korulkin D. Y., Abilov Z. A., Muzychkina R. A., Tolstikov G. A. Natural flavonoids. Novosibirsk, Geo, 2007,229 p.

Надійшла до редакції 17.10.2016 р. 